\title{
External Economic Shocks and Vulnerability of the West African Economic and Monetary Union
}

\author{
Ibrahima Thiam ${ }^{1, ~ *, ~ S a m ~ A g b a h o u n g b a ~}{ }^{2}$ \\ ${ }^{1}$ Economic and Management Department (UFR SES), University of Thies, Thies, Senegal \\ ${ }^{2}$ Economic and Management Department (LAREG), University of Parakou, Parakou, Benin \\ Email address: \\ ithiam@univ-thies.sn (I. Thiam), lesfran.wanilo@gmail.com (S. Agbahoungba) \\ ${ }^{*}$ Corresponding author
}

\section{To cite this article:}

Ibrahima Thiam, Sam Agbahoungba. External Economic Shocks and Vulnerability of the West African Economic and Monetary Union. Journal of Business and Economic Development. Vol. 5, No. 3, 2020, pp. 130-137. doi: 10.11648/j.jbed.20200503.13

Received: June 15, 2020; Accepted: July 7, 2020; Published: July 23, 2020

\begin{abstract}
Background: The regional integration, may it be economic integration or monetary union, is considered, since the success of the European Union, as a mean to development and to mitigate the consequences of exposure to globalization. However, in the African context, the capacity of resilience and the vulnerability of these economies against external shocks remain questionable. Objective: This paper aims to analyze the effects of external economic shocks on the economies of West African Economic and Monetary Union (WAEMU) which is comprised of West African francophone countries (Benin, Cote d'Ivoire, Mali, Niger, Senegal and Togo) and lusophone countries (Bissau Guinea). Method: To achieve this, the Vector Auto Regression technique has been used. We examine the impact of Organization for Economic Cooperation and Development (OECD)'s GDP the price of agricultural commodities, the price of the crude oil barrel, and aid and development assistance shocks on the economies of the union. Due to the lack of data, Bissau Guinea has been removal from the analysis. The data ar primarily sourced from the World Development Indicators and World Economic Outlook databases respectively from the World Bank and the International Monetary Fund and cover the period 1980 - 2018. Results: The results show that the WAEMU countries are highly sensitive to the variations of these different variables with the exception of the price of the crude oil barrel. In addition, the impulse responses show that the WAEMU's economies are permanently affected by these shocks. Conclusion: In terms of economic policy implications, it is essential to strengthen the insurance mechanisms such as intra-trade through the deepening of the regional integration process, responsible budgetary policy, flexibility of the economies, and the economic convergence for the viability of the union.
\end{abstract}

Keywords: Economic Shock, WAEMU, Economic Integration, VAR

\section{Introduction}

The issue of the viability of economic and monetary unions has been of great importance particularly these recent years, probably because of the consequences of economic and financial instability on the different economies. At the international level, since the creation of the euro in the European Union framework, several issues related to the characteristics of economies and the possibilities of nominal and real convergence followed by social and political measures toward the reduction of inequalities between nations have become research topics at the highest level.

In developing countries, economies are seeking to organize themselves around economic and monetary unions in order to have a relative weight on international arena and to gain their place in globalization. However, constraints are sometimes significant because of conflicting economic objectives that each nation is pursuing in the short, medium and long run. In addition, there is the heterogeneous nature of the economies followed by a certain lack of political will. These contradictory objectives and the heterogeneity of the economies require policy coordination at the country and regional level.

In West African countries, one of the major challenges by facing the economic and monetary integration process in recent years has been the establishment of a single currency 
and the strengthening of insurance mechanisms to better cope with internal and external shocks. While the first issue is largely discussed at the highest level, the second is much less so. However, the countries of that region are characterized by instability in production and demand due to recurrent economic and financial instability at the international level. It is therefore important to question economic theories and facts in order to better respond to exogenous shocks and ensure the viability of monetary union, particularly the West African Economic and Monetary Union (WAEMU).

In international monetary relations, the debate relative to the monetary cooperation between nations is framed in the following terms: is it better for a country to give up its monetary autonomy in favor of exchange rate stability? What are the prerequisites for monetary integration or is monetary integration viable and what are the determinants of such integration? Since the successful achievement of monetary integration in some European Union countries, there have been several initiatives towards economic and monetary integration around the world. The theories of optimal currency areas developed by Mundell [1], McKinnon [2] and Kenen [3] and others are the main theoretical foundations for the formation of currency unions. These traditional authors set the groundwork for the monetary unification between two or more countries.

However, beyond the issue of monetary integration, there is the question of the viability. In other words, what are the factors that could ensure the sustainability of the union, improve economic performance while mitigating the impacts of shocks?

On this issue, theoretical developments have focused on the financial market and political shocks, shock symmetry and labor mobility $[4,5]$. For these authors, these factors improve the optimality of an area and would therefore help achieve the expected development objectives. This viability issue is of greater importance because unified economies do not necessarily have strong macroeconomic similarities. To this end, some researchers identified and examined several insurance mechanisms for risk sharing. For example, Cøeuré identified for the case of the European Union the development of financial markets, the flexibility of economies, convergence and responsible fiscal policies as mechanisms to ease the impact of shocks on the EU [6].

WAEMU countries remain vulnerable to exogenous shocks and most of these shocks affect countries in a specific way [7]. Thus, Tapsoba confirms the heterogeneity of shocks between 1965 and 2004 among West African countries by comparing the proportion of the idiosyncratic component of GDP growth rates between these countries and those of the OECD [8]. Other empirical studies doubt the common currency in West Africa based on the high divergence in economic conditions observed in the ECOWAS region. It is shown using the Structural Vector Auto Regression technique that shocks on product are not correlated in WAEMU's zone [9]. Bénassy-Quéré and Coupet [10] and Qureshi and Tsangarides [11] demonstrate by using the cluster classification method that, shocks faced by West African states are highly divergent.
Debrun, Masson and Pattillo have reached a similar conclusion using the terms of trade correlation method [12].

Houssa applied the dynamic and structural factors model and finds a strong heterogeneity of supply shocks in the ECOWAS region [13]. For the case of WAEMU countries, it has been concluded that over the period 1995-2005, there is a certain degree of budgetary convergence towards the target values fixed by political authorities [14]. This is not the case for national budgetary policies because of the presence of a remarkable political heterogeneity. The viability of the union then depends on the implementation and effectiveness of risk-sharing insurance mechanisms. For these countries, Tapsoba identifies two endogenous factors that can mitigate asymmetric shocks and thus enhance the viability of the monetary space [8]. In his view, based on Guillaumont's analyses on WAEMU, the existence of the union itself, by increasing trade and risk sharing among countries, tends to reduce the downside of asymmetrical shocks and increase the optimality of the union. In this regard, WAEMU is undertaking enormous efforts to intensify trade: trade liberalization policies, the ECOWAS Trade Liberalization Scheme (ECOWAS), strengthening regional integration with the implementation of the CET [15].

In addition, West Africa has been engaged in the process of monetary unification. More precisely, it relates to the monetary integration of ECOWAS through the monetary unification of its two subgroups (WAEMU and WAMZ). In view of the successive postponements, it is of crucial importance to analyze the viability of such a project. This article seeks to partially address this issue. Thus, the purpose of this paper is to analyze the impact of economic shocks on certain economic variables for WAEMU countries. In other terms, what do external shocks affect WAEMU's countries and how do they react to such shocks?

Due to the characteristics of space economies, we identify the following exogenous shocks: shock on international income, shock on the price of raw materials such as cotton, coffee-cocoa, oil, and shock on official development assistance (ODA). In fact, African economies produce and export mainly primary goods to emerging/developed countries [16]. In this context, they are potentially exposed to international economic conditions. For instance, a decline in international demand for raw materials as a result of an international industrial crisis would have negative impacts on these economies [17]. Several recent studies have addressed and investigated the vulnerability of African economies to the international economic and financial crisis. This vulnerability occurs through several channels, including the international trade channel [18], the tourism channel [19], the migrant remittances channel [20], the investment channel, the foreign debt channel and others. In this article, the viability is analyzed in this paper as the response of WAEMU economies to these shocks.

The rest of the article is structured as follows. The first section is about the literature review. The second one presents some stylized facts. The third section outlines the methodology used in the study. The fourth section describes 
the variables, data sources and estimation procedures. The fifth presents and analyses the main results. The last one concludes and provides some economic implications.

\section{Selected Literature Review}

There is a relatively recent literature related to studies on the impact of international shocks on African economies. Kose and Riezman analyzed the impact of international shocks on African economies by looking at the relationship between fluctuations in the prices of exported primary goods, imported capital goods, intermediate goods, the world real interest rate and macroeconomic fluctuations in Africa. Their results show that while trade shocks account for $45 \%$ of economic fluctuations of the overall output, financial shocks only have a very slight impact on the latter. In addition, trade shocks also put economies into recession [20]. Nkomo, on the other hand, studied the relationship between changes in world oil prices, energy and development of sub-Saharan African countries [21]. He concluded that oil price shocks increase a country's total import burden. According to him, low-income and poorest countries tend to suffer more from high oil prices. According to Berman and Martin, the international industrial crisis may have significant impacts on African economies because the growth and development of these countries is dependent on the export of raw materials [17]. This led Assoumou-Ella to raise the issue of the existence of a certain link between international economic shocks and economic conditions in Africa [7].

Some studies have analyzed the viability of currency unions in Africa. Most of these studies have focused on the question of the optimality of different areas in Africa. For instance, the research carried out by Houngbédji [22] and Agbahoungba [23] analyzed the optimality of the WAEMU and WAMZ zones respectively. Their conclusions highlight a certain advanced degree of convergence within WAEMU, in contrast to the situation within WAMZ. In the same vein, Tapsoba confirms the heterogeneity of shocks between 1965 and 2004 among West African countries. He compares the proportion of the idiosyncratic component of GDP growth rates between these countries and those of the OECD [24].

Other empirical studies doubt the creation of the single currency in West Africa. These studies are based on the strong divergence in economic trends observed in the ECOWAS region. Fielding and Shields] have shown using the Structural Vector Auto Regression technique that within WAEMU shocks on products are not correlated [31]. Bénassy-Quéré and Coupet [10] and Qureshi and Tsangarides [11], demonstrate using the cluster classification method that the shocks experienced by West African states are highly divergent. Debrun, Masson and Pattillo reach to a similar conclusion using the terms of trade correlation [12]. Houssa applied the dynamic and structural factors model and found a high heterogeneity of supply shocks in the ECOWAS region [13]. By looking at the case of WAEMU countries, the author concluded that over the period 1995-2005, there was some fiscal convergence towards the fixed targeted values [14].
This is not the case for national fiscal policies because of the significant political heterogeneity.

With regard to the analysis of the viability of currency areas in West Africa, two major studies can be mentioned: Tapsoba believes in the existence of endogenous mechanisms capable of mitigating asymmetric shocks and thus ensuring the viability of monetary unions [8]. In the case of WAEMU, the author concludes that intra-zone trade and the development of regional credit markets represent the insurance mechanisms for risk sharing and therefore for the viability of the WAEMU. Coulibaly and Gnimassoun, as far as they are concerned, studied the viability of WAEMU through a model based on convergence and co-movements in the misalignments of exchange rates [25]. In contrast to these studies, other authors have included the impact of international shocks in the analysis of the viability of currency unions. For example, the purpose of Njoroge, Opolot Abuka and Apaa-Okello is to show whether COMESA's monetary union is viable [26]. They use the responsiveness of the countries in this block to internal and external shocks. They concluded that there is scope for the creation of a monetary union in this area. Assoumou-Ella concluded with optimism that it is feasible to achieve monetary unification on the African continental level [7]. To do this, the author compares the reactions of African countries' real GDP per capita to shocks in OECD countries' real GDP per capita, the effective exchange rate of the FED and the price per barrel of crude oil.

\section{Some Stylized Facts}

This section provides a descriptive analysis of the characteristics of the variables indicating the viability of the WAEMU zone based on the evolution of the variables that are likely to cause shocks. This analysis provides an overview of the reactive capacity of WAEMU economies with respect to exogenous shocks. In addition, the analysis of the evolution of risk-sharing insurance mechanisms as assessed by Tapsoba [8] and Tapsoba [24] reinforces the analysis of the viability or otherwise of this union.

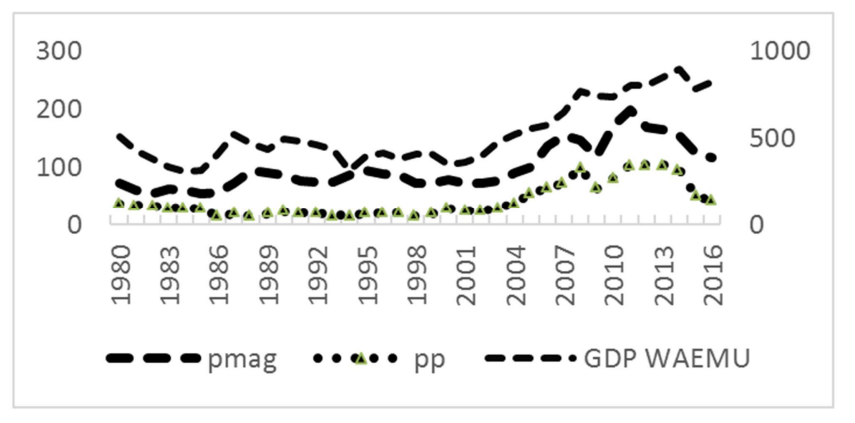

Source: Authors based on WDI, 2019 (WB) and WEO, 2018 (IMF) data.

Figure 1. Trends in the patterns of agricultural commodity price, crude oil and waemu's GDP per capita.

Based on the analysis of this graph, it appears that there is a certain similarity between the price of agricultural raw materials and the price of crude oil. Both curves have similar 
shapes over the entire study period. However, the price of agricultural raw materials was slightly more unstable than that of crude oil during the 1990-2000 period. The sudden drop in both curves is apparently linked to the effects of the 2008 financial crisis. Both curves experienced an upturn in 2010 before experiencing a relatively continuous decline again in 2011 and 2012 due partially to the recent oil crisis. Meanwhile, WAEMU's average GDP per capita is moving at the rate of the two variables, in particular the price of agricultural raw materials. A decrease (or increase) in the price of agricultural commodities results in a decrease (or increase) in the WAEMU's average GDP per capita curve.

This illustrates the relatively high dependency of the welfare level of the region on the worldwide changes in the price of agricultural raw materials. A shock on the latter is likely to have significant economic distortions on the WAEMU's economies.

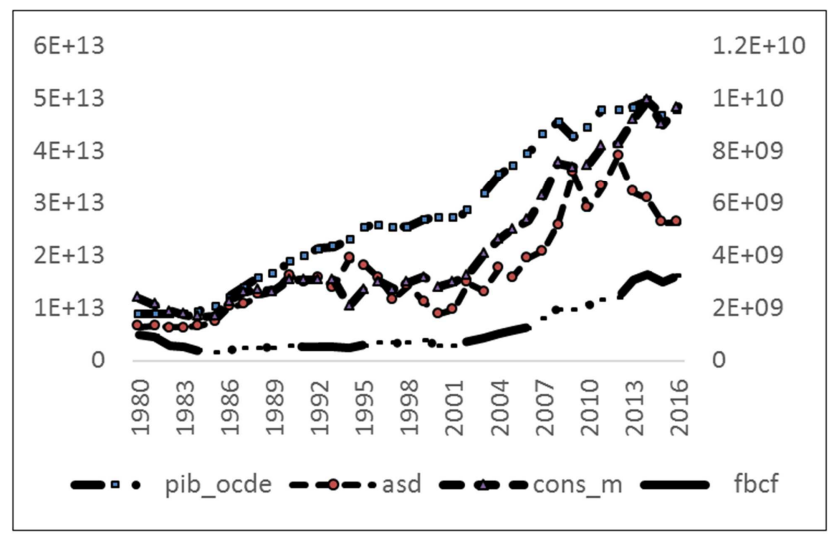

Source: Authors based on WDI, 2019 (WB) and WEO, 2018 (IMF) data.

Figure 2. Trends of patterns of average household consumption and investment in relation to OECD GDP and development aid and assistance.

Three analyses emerge from this graph. Over the period of the study, the curves of total government expenditure in final consumption and investment are combined except starting in 2007 when investments become slightly higher. On average, WAEMU devotes an equal share to public expenditure and investment. However, from 2007 onwards, investment begins to become a more significant priority in WAEMU. The curve of average household consumption expenditure and that of assistance and development aid collected are positively correlated over the period.

However, the decline in consumption observed in 1994 coincides with the year of the devaluation of the FCFA, which could have a negative impact on household consumption expenditure. From 2008 onwards, the decline in assistance and aids is no longer followed by a decline in household consumption expenditures. The latter are now more driven by the increase in general government investment and expenditure in final consumption. Finally, OECD countries' GDP is growing steadily over the entire period. Fluctuations in the latter affect development assistance and aid granted to WAEMU countries, which in turn affect the level of household final consumption expenditure. In short, any shock to development assistance and aid received and to the OECD countries' GDP is a potential source of imbalance and vulnerability for the economies of the WAEMU region.

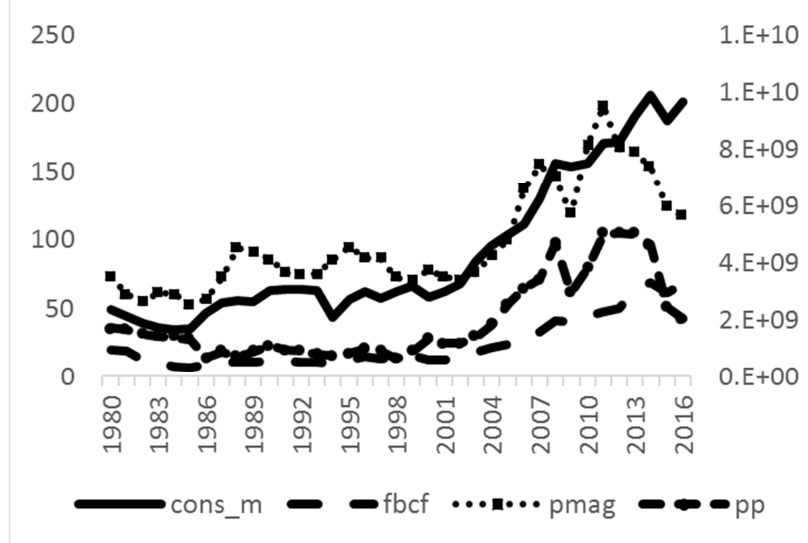

Source: Authors based on WDI, 2019 (WB) and WEO, 2018 (IMF) data.

Figure 3. Trends in average household consumption, and investment patterns in relation to the price of agricultural raw materials and the price of a barrel of crude oil.

Over the whole period, the price of agricultural raw materials is erratic, unlike that of a barrel of crude oil. From 1980 to 1985 and from the 2000 s onwards, the two variables show a relatively strong correlation. However, the variability in the price of agricultural raw materials has a greater impact on the average household consumption expenditure than that of a barrel of crude oil. However, the drop in the prices of these two products (agricultural raw materials and crude oil) has no major impact on average household consumption expenditure in WAEMU, which is henceforth more driven by investments and average government expenditure in final consumption. This reinforces the conclusions of Tapsoba concerning the risk-sharing insurance role of official development assistance for WAEMU's economies in the event of an international shock [8].

\section{Methodology and Data Description}

\subsection{Methodology}

In the empirical part of this study, the VAR approach was adopted. The VAR model has the advantage of capturing the variation of the model's parameters over time and thus making it possible to better reproduce the dynamics of the system, which gives credibility to the economic policy (macroeconomic forecasts) that adjusts and adapts to variations or shocks in the socioeconomic environment. It results from the criticisms formulated by Sims (1980) quoted by Kuma (2018) which can be summed up in the following three points: a priori restrictions (endogenous and exogenous variables are automatically known); arbitrary causal structure (the sense of causality between variables not or wrongly identified); and inadequate treatment of expectations.

There are two traditional VAR modeling tools: shock 
response functions and decompositions of the variance of the forecast error. Let a VAR (p) for a bivariate case (2 variables: $\mathrm{y}$ and $\mathrm{x})$.

$$
\left\{\begin{array}{c}
y_{t}=\pi_{1}+\varphi_{111} y_{t-1}+\varphi_{112} x_{t-1}+\varphi_{211} y_{t-2}+ \\
\varphi_{212} x_{t-2}+\cdots .+\varphi_{p 11} y_{t-p}+\varphi_{p 12} x_{t-p}+\varepsilon_{1 t} \\
x_{t}=\pi_{2}+\varphi_{121} y_{t-1}+\varphi_{122} x_{t-1}+\varphi_{221} y_{t-2}+ \\
\varphi_{222} x_{t-2}+\cdots .+\varphi_{p 21} y_{t-p}+\varphi_{p 22} x_{t-p}+\varepsilon_{2 t}
\end{array}\right.
$$

Where $\varphi_{p i j}$ comprises $\mathrm{p}$ (lag), I (differentiates the coefficients of the variables among equations) and $j$ (differentiates the coefficients among variables in the same equation). By stating:

$$
Y_{t}=\left(\begin{array}{l}
y_{t} \\
x_{t}
\end{array}\right), \pi_{t}=\left(\begin{array}{l}
\pi_{1} \\
\pi_{2}
\end{array}\right) ; \varphi_{t}=\left[\begin{array}{cc}
\varphi_{p 11} & \varphi_{p 12} \\
\varphi_{p 21} & \varphi_{22}
\end{array}\right] \text { and } \varepsilon_{t}=\left(\begin{array}{l}
\varepsilon_{1} \\
\varepsilon_{2}
\end{array}\right),
$$

then the VAR (p) could be written as followed:

$$
Y_{t}=\pi+\sum_{i=1}^{p} \varphi_{i} Y_{t-i}+B M_{t}+\varepsilon_{t}
$$

Where $Y_{t}=\left(y_{1 t}, \ldots \ldots \ldots, y_{k t}\right)$ is a vector of "k" endogenous variables, where each variable constitutes an equation or variable whose value is given by the system. $\pi_{t}=\left(\pi_{1}, \ldots \ldots \ldots, \pi_{k}\right)$ is a vector of " $\mathrm{k}$ " constant terms. $\varphi_{t}=\left(\varphi_{11}, \ldots \ldots \ldots, \varphi_{k k}\right)$ is a square matrix of coefficients of "kxk" order.

To analyze the impact of external shocks on WAEMU's economies, we use the specification used by Gossé and Guillaumin [27] and Assoumou-Ella [7]. We specify three VAR models for each WAEMU's country. $A(L) X_{t}=$ $u_{t} A(L) \mathrm{u}_{\mathrm{t}} \mathrm{u}_{\mathrm{t}} \mathrm{u}_{\mathrm{t}} \sigma^{2} \mathrm{X}_{\mathrm{t}}$

\subsection{Description of Data}

\subsubsection{Description of Variables}

In general, the domestic economy is composed of three (03) VAR models that represent the effects of international shocks on real domestic GDP, household consumption and the investment proxied by the gross formation of fixed capital [7]. The external variables are three (04) types of shocks that have recently affected advanced economies including:

International price shock: the authors Assoumou-Ella [18] and Allegret and Sand-Zantman [28] use the world oil price to represent this shock. In this paper, because of the characteristics of the economies covered here, we add the price of agricultural raw materials to this variable. In fact, as Madeley pointed out, African countries mainly produce raw materials [16]. World income shock: OECD countries' real GDP is a good indicator of this type of shock, according to Assoumou-Ella [7]; Transfer and financial aid shock: we use public development aid as a proxy for this variable. These ODA constitute a significant part of a country's budget. They also help to mitigate certain shocks, particularly asymmetric shocks affecting the economies of West Africa.

Table 1. Description of variables.

\begin{tabular}{lll}
\hline Variables & Description & Nature of shocks \\
\hline LY_OCDE & OECD's gross domestic product. & Exogenous \\
LASD & Inflows aid and official development assistance & Exogenous \\
LPMAG & Price of agricultural raw material in the international market & Endogenous \\
LPP & Price of the barrel of petrol & Exogenous \\
\hline
\end{tabular}

Source: Authors.

The log form of variables are considered in the analytical part to allow for analyzing the coefficients as elasticity and to linearize figures.

\subsubsection{Sources of Data and Estimation Procedures}

The data used in this study come from the World Bank's (WDI) database and the International Monetary Fund's (IMF) WEO. The Im-Perasan-Shin (IPS) tests is used to check for the stationarity of variables before estimating the VAR. To determine the optimal number of lags in the model, we used the AIC (Akaike Information Criterion) criterion. After the estimates, we tested the autocorrelation of the residues (LM test), and the overall stability of the model. Estimates are made using Eviews 9 software and the data cover the period from 1980 to 2018 .

\section{Results and Discussions}

\subsection{Unit Root Tests}

The table below presents the results of the unit root tests for all the variables. The Im, Pesaran and Shin W-stat is preferred to other tests for its relative robustness. Results show that, except for the variable y_ocde that is already stationary at level, hence integrated $\mathrm{I}(0)$, all other variables are non-stationary at level and stationary at the $1^{\text {st }}$ difference, hence they are integrated I(1). In fact, at level, the p-value of the variable y ocde is 0.0093 hence less than $5 \%$ while that of the other variable is greater than $5 \%$. However, the p-values of all variable become equal to zero at the $1^{\text {st }}$ difference level. Considering other unit root tests, the PP-Fisher Chi-square, the variable y_ocde is not stationary at level but stationary at the $1^{\text {st }}$ difference level. So, we assume that all variables are integrated in the same order I(1) and that order does not exceed 1 . Hence, there is a suspicion of the existence of the cointégration relationship.

To test for the cointégration relationships between variables, Pedroni cointégration test has been used. The results (annex 1) indicates that there is no cointégration between variables. In fact, for each of the four statistics proposed by the Pedroni cointégration test, the p-values are greater than $5 \%$. So, we cannot reject the null hypothesis, rather we accept the null 
hypothesis. This implies that there is no cointégration relationship.

Table 2. Unit Root Test Results.

\begin{tabular}{llllll}
\hline At level & & & At 1st difference & & \\
\hline Variables & IPS stat & P-value & IPS stat & P-value & Dec \\
\hline ly_ocde & -2.353 & 0.009 & -5.778 & 0.000 & I(0) \\
lasd & 0.431 & 0.666 & -15.87 & 0.000 & I(1) \\
lpmag & 1.354 & 0.912 & -10.50 & 0.000 & I(1) \\
lpp & 1.654 & 0.951 & -10.45 & 0.000 & $\mathrm{I}(1)$ \\
ly_t & 2.106 & 0.982 & -13.40 & 0.000 & $\mathrm{I}(1)$ \\
lcons_m & 3.871 & 0.999 & -14.43 & 0.000 & $\mathrm{I}(1)$ \\
lfbcf & 2.598 & 0.995 & -12.49 & 0.000 & $\mathrm{I}(1)$ \\
\hline
\end{tabular}

Source: Authors.

\subsection{VAR Estimates and Impulse Responses Results}

The absence of the cointégration relationship allows for running the unrestricted VAR. After checking for the optimal lag, we run the VAR and make the diagnostic tests (Autocorrelation, Heteroskedasticity and normality tests). Out of the three tests, results show that there is no autocorrelation of errors and that overall the errors are normally distributed. The heteroskedasticity test is positive meaning that the errors are not homoscedastic. Although that is not desirable, the absence of autocorrelation and the normality of errors are interesting and allow for running the VAR. The results can be viewed in the annex.

According the objectives of this paper, we are concerned with the reaction of WAEMU's economies against external shocks. So, we derive from the VAR estimates, the impulse responses following external shocks on gross domestic product, household consumption and investment in WAEMU's countries. The results are summarized in the table below.

Table 3. Results of the impulse responses.

\begin{tabular}{|c|c|c|c|c|c|c|}
\hline Period & ly_t & Lcons_m & Ifbcf & ly_t & lcons_m & Ifbcf \\
\hline & LY_OCDE & & & LASD & & \\
\hline 1 & 0.088 & 0.098 & 0.124 & -0.002 & -0.018 & 0.008 \\
\hline 2 & 0.173 & 0.195 & 0.248 & -0.004 & -0.035 & 0.006 \\
\hline 3 & 0.256 & 0.290 & 0.371 & -0.005 & -0.052 & 0.014 \\
\hline 4 & 0.336 & 0.384 & 0.492 & -0.008 & -0.070 & 0.020 \\
\hline \multirow[t]{2}{*}{5} & 0.413 & 0.476 & 0.611 & -0.011 & -0.088 & 0.024 \\
\hline & LPMAG & & & LPP & & \\
\hline 2 & -0.044 & -0.063 & -0.046 & 0.008 & 0.004 & -0.014 \\
\hline 3 & -0.062 & -0.092 & -0.064 & 0.015 & 0.008 & -0.014 \\
\hline 4 & -0.079 & -0.121 & -0.079 & 0.023 & 0.014 & -0.011 \\
\hline 5 & -0.094 & -0.149 & -0.092 & 0.033 & 0.020 & -0.005 \\
\hline
\end{tabular}

Source: Authors.

This table summarizes the results of the estimation of the four (04) different exogenous shocks on four (03) economic variables in the WAEMU sub-region.

1) Response of WAEMU's economies to a shock on OECD's GDP

An international income shock proxied by a shock on OECD's GDP affects positively and significantly on the three selected variables. For instance, $10 \%$ increase in OECD's GDP will lead to $0.88 \%$ increase in WAEMU's GDP in the first year ceteris paribus. This increase will cumulatively reach $4.13 \%$ in the fifth year. The impact of $10 \%$ increase in the OECD's GDP on the household consumption in WAEMU zone is $0.98 \%$ in the first period and could attain $4.76 \%$ in the fifth year. The impact is more important on the investment comparing to the other variables. In fact, $10 \%$ increase of the variable of shock (OECD's GDP) implies $1.24 \%$ increase in the investment variable $(\mathrm{FBCF})$. All these impacts are statistically significant because the p-values are all lesser than $5 \%$. This show the extent to which the WAEMU's economies are vulnerable to the
OECD's wealth, production or economic context.

2) Response of WAEMU's economies to a shock on OECD's aid and development assistance

According to the table above, the GDP and the household consumption in WAEMU negatively react to a shock on the aid and development assistance allocated to WAEMU's member states. More precisely, a 10\% increase the aid and development assistance towards to developing countries (WAEMU's countries) lead to a slight decrease by $0.02 \%$ in the GDP and by $0.17 \%$ in the household consumption for these countries. These decreases could reach $0.11 \%$ in the GDP and $0.87 \%$ in the household consumption in the fifth following year. Even though that result seems somehow contradictory to the theory regarding what aid and development assistance are meant to achieve, it is well explained in the LDCs context.

In fact, several authors highlighted weak institutions, governance, weak negotiation skills, corruption, etc. in those countries to justify the negative impact of aid on the LDC's economies $[29,30]$. On the other, the increase by $10 \%$ in the 
same aid and assistance implies an increase in the investment by $0.07 \%$. This slight impact reflects the positive relationship between the aid and the investment in the receiving countries. However, the increase seems too little faced to the development perspectives in that regional space.

3) Response of WAEMU's economies to a shock on the price of agricultural raw materials

The price of agricultural raw materials exerts a negative and significant effect on WAEMU's economic variables. For instance, a $1 \%$ positive shock on the price of agricultural raw materials would imply a $0.023 \%$ decrease in the gross domestic product (GDP), $0.032 \%$ decrease in the household consumption and $0.024 \%$ decrease in the investment in WAEMU zone the first year. These decreasing impacts may reach cumulatively $0.094 \%$ for the gross domestic product (GDP), $0.149 \%$ for the household consumption and 0.092 for the investment. The results are quite surprising in the light of resources endowment of the WAEMU's countries. In fact, raw materials represent the major export commodities for these countries and should present a positive impact on the economic variables such the GDP, the consumption and the investment. This negative effect could be associated with the deterioration of trade terms as highlighted by Presbisch and Singer with is not profitable for those economies.

4) Response of WAEMU's economies to a shock on the price of the barrel of petrol

The price of a barrel of oil has a significant and positive effect on the level of household consumption expenditures and the GDP in the WAEMU zone. A 1\% shock of the price of the barrel of petrol would lead to a slight increase by $0.0024 \%$, $0.0175 \%$ in the GDP and the household consumption respectively in WAEMU zone. This could be explained by the fact that, any positive shock of the price of barrel of petrol, hence the drop in its price, implies a reduction in manufactured products imported by WAEMU's countries. Then countries are been given an array of products for consumption.

On the other hand, the response of the investment to a shock on the price of the barrel of petrol is negative and statistically significant. For instance, a 1\% increase in that price would provoke a decrease by $0.0097 \%$ in the investment in the first year following the shock. This is explained by the fact that WAEMU's countries do not belong to OPEP. Therefore, the positive benefits resulting from the drop in the price of barrel of petrol do not generate any investment in that zone. This conclusion is in line with several other studies that explain the determinant of investment in petrol endowed countries especially in developing countries.

In summary, WAEMU's economies are very sensitive to changes in many exogenous international variables even though the impact of shocks is somehow small, Thus, WAEMU is highly exposed to international shocks; hence the need to strengthen existing insurance mechanisms such as the development of intra-zone trade and regional credit markets. In addition, other mechanisms such as responsible fiscal policies and economic policy coordination will need to be set up and reinforced to mitigate the vulnerability of the zone.

\section{Conclusion and Implications of Economic Policies}

The objective of this paper was to examine the effect of external economic shocks affecting the countries of the West African Economic and Monetary Union and its reaction against those shocks. This study allows for analyzing the extent to which the WAEMU's countries are vulnerable to the international economic environment. Using the VAR model, we conclude that WAEMU countries are vulnerable to changes in economic activity in OECD countries, changes in assistance and aid, and changes in agricultural raw material prices. A shock on these variables has a lasting impact on WAEMU's economies.

Thus, for the viability of economic and monetary union to be achieved, it is necessary to strengthen insurance mechanisms to limit the effects of these fluctuations, in particular by strengthening stabilization funds and subsidy systems. This requires the diversification of the region by promoting intra-zone trade in order to mitigate shocks. It is therefore important for WAEMU to develop mechanisms of resilience and cyclical regulation in order to significantly reduce the impact of shocks on government spending and income inequality. The above main results can thus be very useful in the prospects for further regional economic and monetary integration, particularly between ECOWAS countries.

\section{References}

[1] Mundell, R. A. (1961). A theory of optimum currency areas', Am. Econ. Rev., vol. 51, no. 4, pp. 657-665.

[2] McKinnon, R. I. (1963). 'Optimum currency areas', Am. Econ. Rev., vol. 53, no. 4, pp. 717-725.

[3] Kenen, P. (1969). The theory of optimum currency areas: an eclectic view. In (Mundell R. and A. Swoboda eds.) "Monetary Problems in the International Economy". Chicago: University of Chicago Press.

[4] Bayoumi, T. and Eichengreen, B. (1994). 'Monetary and exchange rate arrangements for NAFTA', J. Dev. Econ., vol. 43 , no. 1, pp. 125-165, 1994.

[5] Eichengreen, B. (1997). European monetary unification: theory, practice, and analysis. Mit Press.

[6] Cøeuré, B. (2012). 'Les mécanismes d'assurance au sein de l'Union économique et monétaire: avant, pendant et après la crise', Rev. Déconomie Financ, no. 4, pp. 231-242.

[7] Assoumou-Ella, G. (2012). 'Responses of African economies to the international economic shocks: an empirical study', Eur. Econ. Lett., vol. 1, no. 1, pp. 46-51.

[8] Tapsoba, J. A. (2011). 'Union Monétaire en Afrique de l'Ouest: Quelles Réponses à l'Hétérogénéité des Chocs?'.

[9] Fielding, D and Shields, K (2001). 'Modelling macroeconomic shocks in the CFA Franc Zone', J. Dev. Econ, vol. 66, no. 1, pp. 199-223. 
[10] Bénassy-Quéré, A and Coupet, M (2005). 'On the adequacy of monetary arrangements in Sub-Saharan Africa', World Econ., vol. 28 , no. 3 , pp. 349-373.

[11] Qureshi, M. S and M. Tsangarides, M. C. G (2006). What is fuzzy about clustering in West Africa? International Monetary Fund.

[12] Debrun, X, Masson, P and Pattillo, C (2005). 'Monetary union in West Africa: who might gain, who might lose, and why?', Can. J. Econ. Can. Déconomique, vol. 38, no. 2, pp. 454-481.

[13] Houssa, R. (2008). 'Monetary union in West Africa and asymmetric shocks: A dynamic structural factor model approach', J. Dev. Econ., vol. 85, no. 1-2, pp. 319-347.

[14] Sarr, F. and Ndiaye, C. T. (2011). 'Asymétrie et convergence des politiques et chocs budgétaires en zone UEMOA', Rev. Économique Monét. N, vol. 8.

[15] Guillaumont, S (2004). 'Bilan de l'intégration monétaire dans l'UMOA', CERDI.

[16] Madeley, J. (2003). 'Transnational corporations and developing countries: big business, poor peoples', ACP-EU Cour., vol. 196, pp. 36-38.

[17] Berman, N. and Martin, P. (2012). 'The vulnerability of sub-Saharan Africa to financial crises: the case of trade', IMF Econ. Rev., vol. 60, no. 3, pp. 329-364.

[18] Assoumou-Ella, G. (2014). 'International Crises, Characterization of Contagion and Social Well-Being in Developing Countries: A Theoretical Model'.

[19] Naudé, W. A. and Saayman, A. (2005). 'Determinants of tourist arrivals in Africa: a panel data regression analysis', Tour. Econ., vol. 11, no. 3, pp. 365-391.

[20] Kose, M. A. and Riezman, R. (2013). 'Trade shocks and macroeconomic fluctuations in Africa', in International Trade Agreements and Political Economy, World Scientific, pp. 369394.

[21] Nkomo, J. C. (2006). 'The impact of higher oil prices on Southern African countries', J. Energy South. Afr., vol. 17, no. 1, pp. 10-17.
[22] Houngbédji, S. H. (2007). 'Analyse de l'optimalité de la zone monétaire UEMOA dans un contexte d'intégration', Maitrise En Sci. Econ. Univ. Parakou Bénin.

[23] Agbahoungba, S. (2012). 'Analyse de l'optimalité de la ZMAO (Zone monétaire de l'Afrique de l'Ouest) dans un contexte d'intégration', Maitrise En Sci. Econ. Univ. Parakou Bénin.

[24] Tapsoba, J. A. (2009). 'Intégration monétaire africaine et changements structurels: commerce, partage des risques et coordination budgétaire', $\mathrm{PhD}$ Thesis, Université d'Auvergne-Clermont-Ferrand I.

[25] Coulibaly, I. and Gnimassoun, B. (2013). 'Optimality of a monetary union: New evidence from exchange rate misalignments in West Africa', Econ. Model., vol. 32, pp. 463$482,2013$.

[26] Njoroge, L. K, Opolot, J, Abuka, C and Apaa-Okello, J. (2011). 'Nature and Extent of Shocks in COMESA: Implications for a Monetary Union', Interdiscip. J. Res. Bus., vol. 1, no. 3, pp. 2346.

[27] Gossé J. B. and Guillaumin, C. (2010). 'L'impact des chocs externes sur et à l'intérieur de la zone euro: les enseignements d'un modèle vectoriel autorégressif structurel', Econ. Previs., no. 4, pp. 15-33.

[28] Allegret, J. P. and Sand-Zantman, A. (2010). 'Processus d'intégration et coordination des politiques macroéconomiques dans le MERCOSUR: une approche en termes de cycles', Actual. Économique, vol. 86, no. 2, pp. 163-204.

[29] Abdoulaye, D. (2017) 'Droits de Propriété, corruption et croissance économique dans les Pays de l'UEMOA : Une analyse de la causalité au sens de Granger', Afr. Integr. Dev. Rev., vol. 10, pp. 87-106, 2017.

[30] Adedodja, E. A. and Sirpe, G. (2019). 'Corruption et pauvreté dans les pays de l'UEMOA', Ethique et économique/Ethics and Economics, vol. 2, no. 16, p. 14.

[31] Fielding, D. and Shields, K. (2001). "Modelling macroeconomic shocks in the CFA Franc Zone » Journal of Economic Development, Vol. 66, Issue 1, October 2001, Pages 199-223. 